\title{
From illustrated text to picturebook: Astrid Lindgren's “Mirabelle”
}

During the last few years, several of Astrid Lindgren's early stories have been turned into picturebooks. In this article I would like to take a closer look at what happens to a story when it develops from an illustrated text to a picturebook with an iconotext.

\section{From "Mirabelle" to Mirabell}

My example is Astrid Lindgren's story "Mirabelle" (Lindgren 1949). "Mirabelle" is the story of a rather lonely girl, Britta, who has an ardent wish for a doll. But her parents are poor, and they are unable to give her what she most wants. However, one day an odd little old man arrives driving a horse and cart. Britta opens the gate for him, and he thanks her by giving her a tiny seed that shines like gold. He instructs her to plant the seed in the garden and water it well every day. One morning, as Britta comes to water her seed, something red is sprouting out of the soil. Every day it grows bigger and bigger. From the golden seed a doll grows up, and she is exactly what Britta has wanted. It is the most beautiful doll she has ever seen - and her name is Mirabelle. Mirabelle looks exactly like any ordinary doll, but when she is alone with Britta, she comes alive. She can talk and eat just like any ordinary human being.

"Mirabelle" was first published in 1949 in the anthology Nils Karlsson-Pyssling ("Simon Small"). It then appeared as an illustrated text with black and white drawings by Eva Billow. In 1967 the story was republished in the anthology Salikons rosor ("Salikon's roses"), illustrated by Ilon Wikland. This anthology was later, in 2003, published as an audio book - read by Astrid Lindgren. In 2002 the story was published as a picturebook - illustrated by Pija Lindenbaum. It is interesting to see what happens when Astrid Lindgren's story is transformed into a completely different genre, the picturebook, where words and pictures are expected to constitute a unity. Does the 
picturebook illustrator have something to add to the original text? And how do the pictures change Astrid Lindgren's original story?

To read a picturebook is to read an iconotext (Hallberg 1982, 165) - a synthesis of words and pictures. A picturebook is mainly mediated through the two modalities of the iconotext - writing and images/ drawings/pictures - thereby constituting a multimodal text. All modalities have varying limits to what they can express and the ways in which they can express something to a reader. For instance: writing can easily inform us about the names of characters and places, give us information about the characters' age and background, reproduce speech, and mediate the relations between the characters in the book. This is information that may be difficult to communicate with any precision through the modality of the picture. A picture, however, can offer more specific information about what the characters look like, the characters' surroundings and environment, colours, where the characters are situated in relation to each other in space, how a person executes various tasks, etc. The modalities have various intrinsic possibilities and limitations when it comes to representing and communicating something to a reader. This is what the social semiotician Gunther Kress calls modal affordance (Kress 2003,14). The question then is how the illustrator Pija Lindenbaum exploits the potential inherent in the pictures as she transforms the "Mirabelle" story into the picturebook Mirabell.

\section{The picturebook expands the original text}

Even an illustrator is first and foremost a reader, a reader who is dependent on gaps in the verbal text in order to contribute successfully something new to the story. According to Wolfgang Iser, one can never say everything in a fictional text. The author always has to make choices, and this results in what Iser calls gaps or blanks or places of indeterminacy or vacancies in the text (Iser 1978). The most important mission for these textual gaps is to disturb the reading process. The reader is given choices, and is therefore invited to be an active reader.

Like other fictional texts, Astrid Lindgren's "Mirabelle" has several gaps or blanks. For instance, the information given about the main character, Britta, is limited. In the opening scene, she states her age and her name, but in the next sentence she claims that her name is not important: "My name is Britta, although that really isn't part of the story" (Lindgren 2003). We are told that she longs for a doll of her own, but that her parents cannot afford to buy her one. The 
main character, who is also the narrator, informs us that she lives "in a tiny house with a little garden around it. Our house is far away from everything, and no one lives nearby"(Lindgren 2003). Other than this, the information she gives about herself is extremely limited in Lindgren's original text. She does not describe her appearance nor how she spends her days. These, and several other gaps, invite the reader - and the illustrator - to fill these places of indeterminacy with their own imagination and life experience.

The picturebook Mirabell expands Astrid Lindgren's original story in several different ways. Let us start by looking at the paratexts of the picturebook. While Lindgren's verbal story opens with the main character promising to tell us something odd that happened to her two years ago, the picturebook anticipates the plot on the book cover. According to Maria Nikolajeva and Carole Scott

/--/ the cover of a picturebook is often an integral part of the narrative, especially when the cover picture does not repeat any of the pictures inside the book. The narrative can indeed start on the cover, and it can go beyond the last page onto the back cover. (Nikolajeva and Scott 2001, 241)

On the front cover of Mirabell, we see a girl with a doll. They are sitting in a vegetable garden, and the girl holds her doll up as though showing it to a hen at the front right of the picture (see illustration 1). While Astrid Lindgren's verbal story opens by presenting an apparently lonely child, the picturebook starts by showing us a girl in seemingly happy environment. Admittedly, she is not in the company of other persons, but the surroundings seem idyllic, and she is not alone. A warm, green colour - a colour symbolising hope, spring and new life - dominates the front cover in addition to the red colour of the doll, the girl's dress, the hen and the roses in the background.

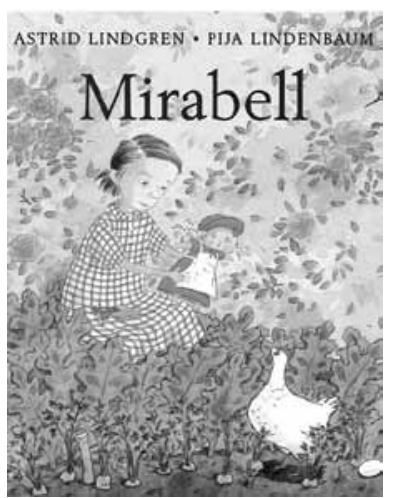

The picture is unique, it is not repeated in the book, and as we read the book we realise that the action represented on the front cover takes place some time after the seventh double-spread in the main story.

Pija Lindenbaum's expansion of Astrid Lindgren's verbal story continues as we turn the pages to get to the main story.

III. I. (C) Astrid Lindgren. Mirabell. III. Pija Lindenbaum. Stockholm: Rabén \& Sjögren, 2002. 


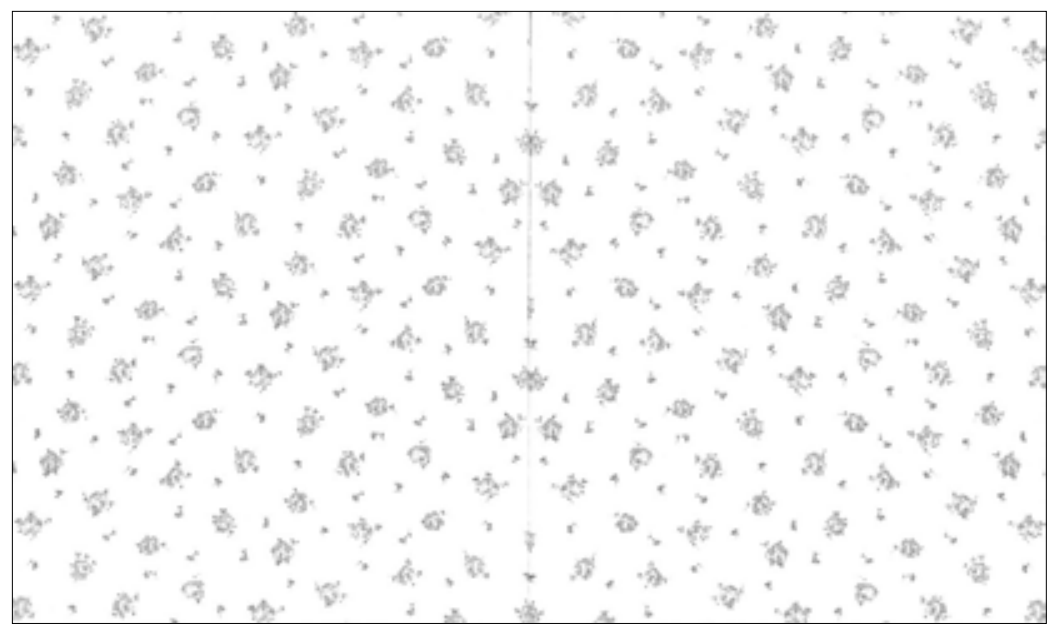

III. 2. @Astrid Lindgren. Mirabell. III. Pija Lindenbaum. Stockholm: Rabén \& Sjögren, 2002
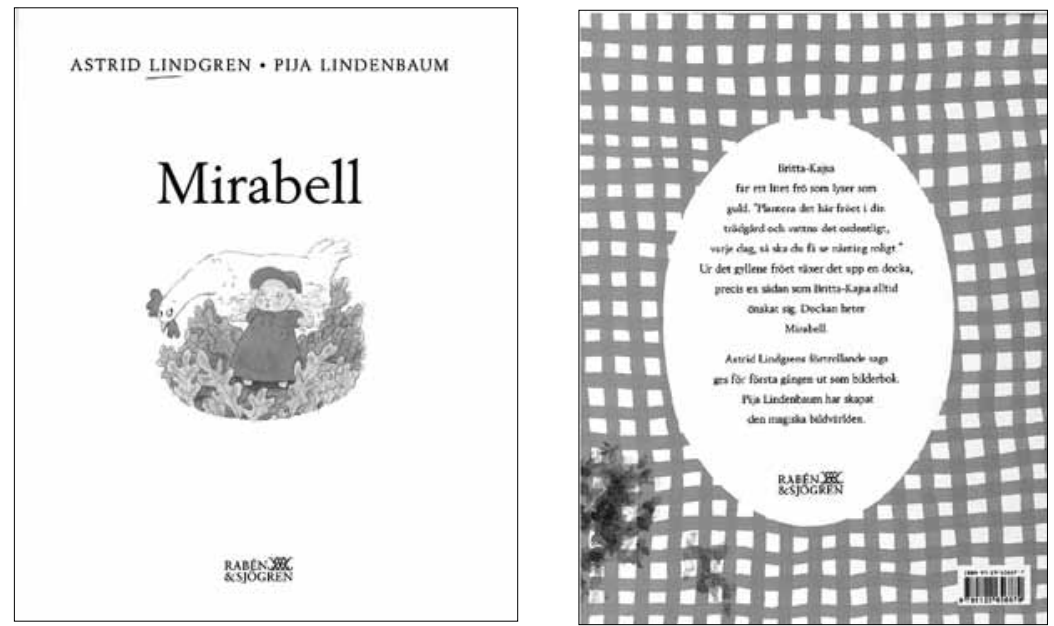

III. 3, 4. @Astrid Lindgren. Mirabell. III. Pija Lindenbaum. Stockholm: Rabén \& Sjögren, 2002.

The endpaper anticipating the main story shows idyllic roses (see illustration 2), and the prologue picture on the next title page focuses on the doll and the hen we first encountered on the front cover (see illustration 3). This prologue picture alerts the reader to follow the presence of the hen in the main story. I shall return to this element in Lindenbaum's pictures.

Only when we have turned the pages of the initial paratexts, do we reach Astrid Lindgren's opening of the story. The story is expanded in a similar manner when the last word has been read. The rosy endpaper is repeated after the main story, giving the story a soft and dreamy frame (see illustration 2), and the back cover shows 


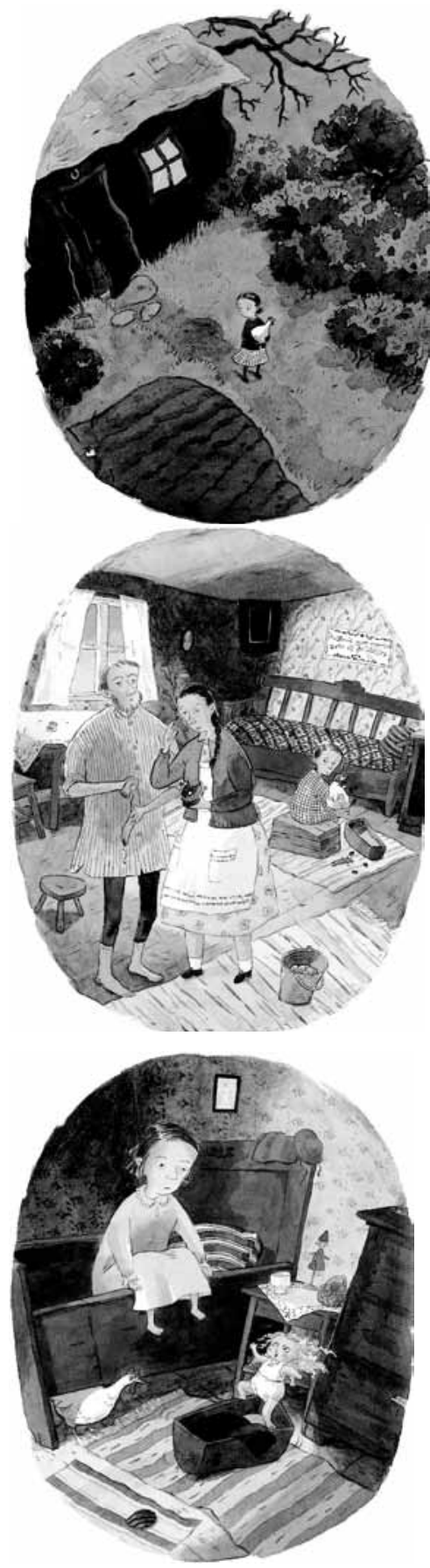

III. 5, 6, 7. @Astrid Lindgren. Mirabell. III. Pija Lindenbaum. Stockholm: Rabén \& Sjögren, 2002. a square pattern which I interpret to form part of the main character's dress. And if we look closely, we observe that it has been soiled - probably by Mirabelle, who, as we learn from the main story, is a naughty little doll (see illustration 4).

By exploiting the modal affordance - the inherent possibilities and limitations - in the pictures, we see that Pija Lindenbaum expands Astrid Lindgren's story by creating a frame around the main storyline. This frame prepares for the story we are about to read and it also provides a softer, more gradual introduction to and ending of the story. This expansion of the text is obviously not concerned with the addition of the modality of the picture alone. It is equally important that now, for the first time, the story has been published as an independent book, which gives it more scope than in earlier publications when it had to share the space with other texts. In accordance with common practice in modern picturebooks, the illustrator is free to introduce pictures that may both precede and succeed the main story.

The pictures also expand the original story by exposing the information communicated through Astrid Lindgren's verbal story. In this respect the colours certainly play an important part. Astrid Lindgren uses colours only when describing the Mirabelle doll: "She had blond curly hair under the red hat, pink cheeks, and a red mouth. Slowly the entire body grew. She had a really pretty dress made of the same fabric as the hat" (Lindgren 2003).

Pink and red then are the most conspicuous colours in Astrid Lindgren's text, and the illustrator accentuates the use of the pink and red shades in her pictures. These colours show up in the clothes both of the main character and of the doll, on the hen, the roses in the garden surrounding the house, and on the bedlinens and the rugs in the main character's room. The 
red colours are enhanced by means of the excessive use of the green contrast colour in the natural surroundings outside and indoors. At the same time the warm, red tones symbolize the companionship that the main character experiences with the doll Mirabelle - in her Britta has found a true friend.

But while Astrid Lindgren uses colours only to describe the doll, Pija Lindenbaum exploits the possibilities inherent in the use of colours to create an atmosphere. In doublespread number three, where the main character begins her story about the weird events that took place two years ago, Astrid Lindgren writes that, "There was something unusual in the air"(Lindgren 2003). The illustrator captures this feeling of strangeness by creating a magical and mysterious atmosphere around the main character - and she does so primarily by colouring the pictures in pink, lilac, and black (see illustration 5). These colours dominate double-spreads three and four and the first half of double-spread five. These pages span the time from the main character's encounter with the strange man who comes visiting and until she has planted the seed he gives her.

Readers meet the hen for the first time on the front cover. The hen recurs in all the doublespreads in the picturebook and is an independent element in the story communicated by the illustrations. The hen is not present in Astrid Lindgren's original text; it is an element only present in the pictures. Until Mirabelle enters the life of the main character, it is the hen that keeps Britta company. They are always together, and Britta uses the hen as a doll - she dresses it and it is allowed to sleep in the doll's bed that later becomes Mirabelle's bed (see illustration 6). As Mirabelle enters the scene, however, the hen is pushed to the side, which she does not like at all (see illustration 7). Lindenbaum then exploits her modality to supply the story with a minor parallel story - a story within the story - and thus embellishes the original story even further. By adding a parallel story, the illustrator expands the original story and gives the reader more gaps to fill. We can relate to the obviously jealous hen that acts similar to a child who has just become a big brother or sister.

\section{The picturebook limits the places of indeterminacy}

The illustrator, however, also fills gaps in the original text that take away some of the magic of the original story. For instance, when the narrator tells us about the strange thing that happened two years ago:

It was a strange evening. The garden and our house and the 
lane - everything looked so different. There was something unusual in the air. I can't explain how peculiar it was (ibid.).

In Astrid Lindgren's original text, this paragraph is an important gap that the reader is invited to fill with his or her imagination. But in the picturebook, this opportunity is partially taken away from the reader. Here we are served the illustrator's interpretation of what this strange evening looked like. As I have already mentioned, the colours pink, lilac, and black dominate the pictures, and the house and the tree behind it almost look alive (see illustration 5).

Something similar happens when it comes to the main character. The information given to us by Astrid Lindgren is extremely limited. It is up to the reader to imagine what she looks like. But in the picturebook, this opportunity is taken away.

The same goes for the illustrator's use of colours. While Astrid Lindgren only uses colours when describing the Mirabelle doll, the illustrator expands the use of the pink and red colours introduced by Astrid Lindgren, and she uses the colour green quite often. This is positive in the way that it makes the story more stringent. We can follow the red

III. 8. (C)Astrid Lindgren. Mirabell. III. Pija Lindenbaum. Stockholm: Rabén \& Sjögren, 2002.

Pappa har snickrat henne en säng, sả att hon slipper ligga i symaskinshuven. Mamma har sytt lakan och täcke àt henne. Och jag har sytt ett fint nattlinne och flera förkläden och en vardagsklänning. Mirabell blir sả glad, när hon fảr nágot nytt. Jag leker med henne hela dagarna utom năr jag mảste hjälpa pappa att rensa $i$ trädgárden.

Varje gảng jag hör en hästskjuts pả vägen, rusar jag ner till grinden för att se, om det inte kan vara den lilla underliga gubben, som kommer ảkande igen. Jag ville sá gärna fả tacka honom för min vackra, vackra docka. Men han kommer aldrig.

Skulle ni vilja se min docka, min vackra, fina Mirabell? Kom och hälsa pá mig, sả ska ni fả se henne. Det är bara att följa den lilla smala văgen, som leder till vár stuga. Jag lovar, att jag ska stả med Mirabell vid grinden. 
and pink colours throughout the book, but by portraying a green and pink and red environment for the main character, the illustrator also makes the story happier and more idyllic early in the text.

As we can see from these examples, when Pija Lindenbaum fills the gaps in the original text, she potentially limits the places of indeterminacy for the reader. The illustrator's imagination becomes a substitute for the reader's own imagination - the reader is given fewer choices.

\section{Something old? Or something new?}

The picturebook Mirabell is a different story than Astrid Lindgren's "Mirabelle". To be more precise, the picturebook offers Astrid Lindgren's story AND the illustrator Pija Lindenbaum's interpretation of the original story. As readers we have been given something new through the illustrator's interpretation, but we might also have lost something along the way.

Astrid Lindgren ends her story by having the main character invite the readers to visit her:

Would you like to see my doll, my beautiful, elegant Mirabelle? Come and say hello to me and you'll get to meet her. Just follow the narrow lane that leads to our house. I promise I'll be standing at the gate with Mirabelle. (Lindgren 2003)

Through the pictures we get a foretaste of such a visit. In both the first edition of the story with black and white pictures by Eva Billow as well as in the picturebook with colour illustrations by Pija Lindenbaum (see illustration 8) we see the main character standing with Mirabelle at the gate. Billow's and Lindenbaum's illustrations have in a way already granted us a visit with Britta and her beloved Mirabelle. The visit is not entirely left to our imagination as is the case, for instance, when we listen to the audio book or read the story without watching the pictures.

There can be no doubt that Astrid Lindgren's original story, "Mirabelle", works perfectly well without pictures. The author's lyrical and colourful language invokes pictures and moods in a range of readers, from young to old, inexperienced to experienced readers.

The picturebook is a beautiful and valuable contribution to the long series of books in Astrid Lindgren's extensive authorship. By giving the story a new space within the frames of the picturebook and by exploiting the potential inherent in the modality of the picture, 
Pija Lindenbaum manages to give the story of lonely Britta even more warmth and pleasure than Lindgren grants in the original text.

The illustrator and the picturebook genre give us a story of a girl that is less lonely than in the original text. Some of the longing for the doll is gone, because the reader sees that the main character will be given a doll before he or she sees the book cover or reads about the wish for the doll in the opening scene. The paratexts provide, as I have already mentioned, a softer and more gradual introduction and ending to the story, but it also takes away some of the thrill of wondering whether the main character will ever get a doll of her own or not. This is my main criticism of this picturebook. Astrid Lindgren's authorship is filled with books and stories about lonely children who somehow manage to become a little less lonely - often by finding the powers within themselves and by "a little help from their friends", or rather: with a little help from new friends.

In this picturebook, the contrast between the lonely and bored girl in the beginning of the story and the girl with a happy life and a doll of her own, a doll that is also her best friend, is somehow minimized. The contrast is less striking in the picturebook than in the original story, and that makes the story a bit less exciting to read, or at least a bit less typical of Astrid Lindgren.

\section{Bibliography}

Hallberg, Kristin. "Litteraturvetenskapen och bilderboksforskningen". Tidskrift för litteraturvetenskap (1982) 3-4: 163-168.

Iser, Wolfgang. The act of reading: a theory of aesthetic response. Baltimore and London: The Johns Hopkins UP, 1978.

Kress, Gunther og Carey Jewitt (ed.). Multimodal literacy. New York: Peter Lang, 2003.

Lindgren, Astrid. Nils Karlsson-Pyssling. Ill. Eva Billow. Stockholm: Rabén \& Sjögren, 1949.

Lindgren, Astrid. Salikons rosor. Ill. Ilon Wikland. Stockholm: Rabén \& Sjögren, 1967.

Lindgren, Astrid and Pija Lindenbaum: Mirabelle, trans. Elisabeth Kallick Dyssegaard. Stockholm: (R \& S Books) Rabén \& Sjögren, 2003 [orig. 2002].

Nikolajeva, Maria and Carole Scott. How picturebooks work. New York: Routledge, 2001. 